\title{
SYNTHETIC INDICATORS OF SUSTAINABLE DEVELOPMENT AND THE ROLE OF HUMAN CAPITAL
}

\author{
Biljana Jovanović Gavrilović ${ }^{1}$ \\ Biljana Radivojević ${ }^{2}$
}

DOI: https://doi.org/10.31410/ERAZ.2019.297

\begin{abstract}
With the adoption of the Agenda 2030, the concept of sustainable development was formally accepted as the dominant development paradigm at the global level. Sustainability in the context of sustainable development does not mean maintaining the status quo, but preserving development opportunities, which is very important for future generations, as well as from the point of view of measuring sustainable development. Among the synthetic indicators that measure sustainable development in a comprehensive manner, special attention should be paid to wealth of nations and adjusted net saving. Wealth is broadly defined to include produced capital, natural capital, human capital, and net foreign assets. Human capital, according to research by the World Bank is the most important component of wealth at the global level and for most countries. The convergence in wealth that is observed between middle-income and high-income countries during the period 1995-2014 is mostly due to the accumulation of human capital, which have raised from massive investments to improve education and health outcomes. The aim of the paper is to point out the significance of measuring sustainable development, as well as the advantages in the use of synthetic indicators, such as wealth and related adjusted net saving. The focus is on the role of human capital in selected synthetic indicators as the leading factor for sustainable development in the 21st century. Measuring of changes in the volume and composition of total and per capita wealth over 20 years in 141 countries, carried out by the World Bank, permits us to monitor, analyze and compare the sustainability of development process worldwide. This is also possible by using adjusted net saving, which help us understand some of the dynamics that drive the changes in wealth. Paper also provides insight into how available wealth and adjusted net saving data can be used to guide a policy towards sustainable development.
\end{abstract}

Keywords: Sustainable development, synthetic indicators, wealth of nations, adjusted net saving, human capital.

\section{INTRODUCTION}

lthough most of the world's countries are exposed to a strong pressure from short-term prior-
lities, there has been a huge increase of interest in economic development sustainability at the
long run. This is supported by the fact that the Millennium Development Goals, the realization of
which is timed by 2015, are replaced by a new global development agenda focused on achieving
the Sustainable Development Goals in the next fifteen-year period. Sustainability in the context
of sustainable development does not mean maintaining the status quo, but preserving develop-
ment opportunities [1]. This implies responsible behavior towards future generations, regardless
of the fact that they do not have the right to vote and cannot influence the creation of a current
policy. Sustainable development represents a new approach to understanding development, which

1 University of Belgrade - Faculty of Economics, Kamenička 6, 11000 Belgrade, Serbia

2 University of Belgrade - Faculty of Economics, Kamenička 6, 11000 Belgrade, Serbia 
is substantially different from the paradigm of conventional development. It is expected from the sustainable development to better link short- and long-term development horizon, to place at the same level social, environmental and economic interests, to effectively harmonize the social and individual scale of preferences and interests, to correct market failures and internalize the social and environmental in economic expenses, to minimize the failures of the state through the development of a partnership between the state, private sector and civil society [2].

In order to monitor the progress of individual countries towards sustainable development, it is necessary to define appropriate indicators of this process. Multidimensionality of sustainable development, which encompasses economic, social and ecological component, makes its measurement very difficult. In the literature, various measures of sustainable development are defined, among which special attention deserve synthetic indicators that measure sustainable development in a comprehensive manner. This group includes complex indicators such as national wealth and adjusted net saving.

\section{NATIONAL WEALTH AND ADJUSTED NET SAVING AS A SYNTHETIC INDICATORS OF SUSTAINABLE DEVELOPMENT}

The concept of national wealth is broadly defined to include different types of capital: produced capital, natural capital, human capital, and net foreign assets. There is a close connection between the indicators of national wealth and sustainable development. While the Brundtland Commission defined sustainable development from the point of view of meeting the needs of current and future generations, in later interpretations, the emphasis is on preserving and increasing the opportunities available to people in different parts of the world and at various points of time (as it became clear that needs cannot be so easy to compare between countries and over time). Thus, from the indicators of the flow of economic activity (such as gross domestic product), the focus has shifted to the indicators of stocks of different forms of capital. Total national wealth, ultimately, determine the opportunities that people will face.

The process of sustainable development is, in essence, the process of creating and maintaining wealth, that is, managing such wealth. Putting an emphasis on wealth suggests a new approach to economic development. Unlike traditional concept of development, which in the first place has the construction of infrastructure, development is now understood as «portfolio management», i.e. the process of managing a portfolio of different types of capital, in order to preserve and multiply the opportunities available to people [3].

Wealth, provides useful information to policymakers. Decreasing total wealth per capita is a clear sign that country's development is not sustainable. On the other hand, preserving stocks of wealth or their increase provides the basis for maintaining or improving well-being.

Adjusted net saving (ANS) is a complementary synthetic indicator of sustainable development, which provides a better understanding of the process of wealth-building on an annual basis. Unlike national wealth as a measure of stock, it is a measure of flow, which indicates changes in the wealth of the country.

The procedure for calculating ANS can be presented in four steps. First of all, gross national saving is reduced by the depreciation of produced capital in order to obtain net saving. Then, current education expenditures, which are treated as investments in human capital, are added to 
net saving. In the next step, the estimated amount of resources depletion (subsoil assets, timber resources) is subtracted. Finally, when the cost of air pollution damage to human health is deducted, remains the so-called adjusted net saving [4].

Measurement of ANS provides an additional set of information for policy makers. Permanent negative saving clearly shows that the economy is not moving along the path of sustainable development, i.e. that opportunities to increase future well-being may be wasted for short-term gains. Conversely, if ANS is positive, it adds to wealth and future well-being. Breaking ANS into components makes it easy to take policy interventions to improve nation's ANS, such as increasing investment in education to boost human capital, improving air quality to reduce pollution damage costs, etc.

\section{TRENDS IN WEALTH OF NATIONS AND ADJUSTED NET SAVING WITH SPECIAL EMPHASIS ON THE IMPORTANCE OF HUMAN CAPITAL}

The need and interest for measuring national wealth are relatively recent and closely connected with the affirmation of the concept of sustainable development. The World Bank recently published a third report on wealth, which covers 141 countries of the world during the period 1995-2014 [5].

Unlike previous reports, total wealth is now calculated by adding the estimates of each of its components: produced capital, natural capital, human capital, and net foreign assets. For the first time, human capital is estimated directly on the basis of household surveys for all countries. It is calculated as the net present value of earnings over a person's lifetime.

Table 1: Wealth, by Income Group, 1995-2014

Source: Lange, G-M., Wodon, Q., Carey, K. (eds.) (2018), p. 45

\begin{tabular}{|l|c|c|c|c|}
\hline \multicolumn{4}{|c|}{ Tealth (US\$) } \\
\hline Aggregate (billions) & $\mathbf{1 9 9 5}$ & $\mathbf{2 0 1 4}$ & $\mathbf{1 9 9 5}$ & $\mathbf{2 0 1 4}$ \\
\hline Low-income countries & 3,616 & 7,161 & 11,601 & 13,629 \\
\hline $\begin{array}{l}\text { Lower-middle-income } \\
\text { countries }\end{array}$ & 35,249 & 70,718 & 17,718 & 25,948 \\
\hline $\begin{array}{l}\text { Upper-middle-income } \\
\text { countries }\end{array}$ & 95,105 & 247,793 & 51,142 & 112,798 \\
\hline $\begin{array}{l}\text { High-income non-OECD } \\
\text { countries }\end{array}$ & 40,886 & 76,179 & 163,827 & 264,998 \\
\hline $\begin{array}{l}\text { High-income OECD } \\
\text { countries }\end{array}$ & 515,086 & 741,398 & 547,419 & 798,389 \\
\hline World & 689,942 & $1,143,249$ & 128,929 & 168,580 \\
\hline
\end{tabular}

Based on the available data in Table 1, between 1995 and 2014 global wealth grew by a continuous average annual growth rate of $2.7 \%$, and wealth per capita at a rate of $1.4 \%$ [calculated by the authors]. Growth in total wealth was followed by a significant reduction in its concentration in high-income countries, whose share declined from $75 \%$ to $65 \%$, with a simultaneous increase in the share of middle-income countries from $19 \%$ to $28 \%$, especially those that are somewhat more developed (higher-middle income).

However, inequality in the distribution of wealth is still very pronounced, as evidenced by the fact that low-income countries participate in the total wealth with less than $1 \%$ in 2014 and that 
their share has remained almost unchanged compared to two decades ago. The per capita wealth of high-income countries in 2014 is 52 times higher than in low-income countries, and this ratio is worse.

A composition of total wealth also deserves attention. Human capital makes a lion's share of the wealth in the observed countries, although its share in total wealth declined from $69 \%$ in 1995 to $64 \%$ in 2014 . This decline was registered only in richer countries, while in most developing countries, the share of human capital in total wealth is on the rise. The established trend will continue, as qualified labor is the key to future development in the face of rapid technological changes. According to the share in total wealth, after the human capital comes the produced capital, whose share over the observed period increased from $24 \%$ to $27 \%$, and the natural capital that increased from $8 \%$ to $9 \%$ [5]. Natural capital is the most important in the initial stages of development when it significantly exceeds the produced capital. In countries with a middle level of income, its relative importance is roughly as produced capital. The continued importance of natural capital in low- and middle-income countries suggests that the management of natural resources should be an important part of their development strategy.

Table 2: Human capital per capita, by Income Group, 1995-2014

Source: Lange, G-M., Wodon, Q., Carey, K. (eds.) (2018), p. 123

\begin{tabular}{|c|c|c|c|}
\hline & 1995 & 2014 & $\begin{array}{c}\text { Annual growth } \\
\text { (\%) }\end{array}$ \\
\hline $\begin{array}{l}\text { World } \\
\text { Human capital per capita (US \$) } \\
\text { Human capital as share of total wealth per capita (\%) }\end{array}$ & $\begin{array}{c}88,874 \\
69\end{array}$ & $\begin{array}{c}108,654 \\
64\end{array}$ & 1.06 \\
\hline $\begin{array}{l}\text { Low-income countries } \\
\text { Human capital per capita (US \$) } \\
\text { Human capital as share of total wealth per capita (\%) }\end{array}$ & $\begin{array}{c}3,921 \\
34\end{array}$ & $\begin{array}{c}5,564 \\
41\end{array}$ & 1.86 \\
\hline $\begin{array}{l}\text { Lower-middle-income countries } \\
\text { Human capital per capita (US \$) } \\
\text { Human capital as share of total wealth per capita (\%) }\end{array}$ & $\begin{array}{c}7,992 \\
45\end{array}$ & $\begin{array}{c}13,117 \\
51\end{array}$ & 2,64 \\
\hline $\begin{array}{l}\text { Upper-middle-income-countries } \\
\text { Human capital per capita (US \$) } \\
\text { Human capital as share of total wealth per capita (\%) }\end{array}$ & $\begin{array}{c}31,906 \\
62\end{array}$ & $\begin{array}{c}65,742 \\
58\end{array}$ & 3,88 \\
\hline $\begin{array}{l}\text { High-income non-OECD countries } \\
\text { Human capital per capita (US \$) } \\
\text { Human capital as share of total wealth per capita (\%) }\end{array}$ & $\begin{array}{c}57,319 \\
35\end{array}$ & $\begin{array}{c}111,793 \\
42\end{array}$ & 3.58 \\
\hline $\begin{array}{l}\text { High-income OECD countries } \\
\text { Human capital per capita (US \$) } \\
\text { Human capital as share of total (\%) }\end{array}$ & $\begin{array}{c}408,992 \\
75\end{array}$ & $\begin{array}{c}498,399 \\
70\end{array}$ & 1.05 \\
\hline
\end{tabular}

Table 2 presents the level and dynamics of human capital, as well as its share in the total wealth per capita in the analyzed period. Data show that for two decades in low-income countries, the share of human capital has increased from $34 \%$ to $41 \%$, and in lower-middle income countries from $45 \%$ to $51 \%$. Many of these countries are experiencing a demographic transition accompanied by a slowdown in the rate of population growth, while at the same time improving its educational level. On the other hand, in countries with upper-middle income level, the share of human capital in the total wealth per capita fell from $62 \%$ to $58 \%$, and in the high-income OECD countries from $75 \%$ to $70 \%$. However, it is clear that at higher levels of development, human capital is decidedly dominant. 
An overview of growth rates in human capital wealth reveals that human capital growth is faster in countries with lower- or middle-income level than in developed ones, which points to a convergence process. This is even more pronounced when considering individual countries, because aggregated data give greater weight to larger countries.

Analysis by geographical regions, which includes low- and middle-income countries, provides an additional insight into the creation of wealth per capita, as a superior indicator of development than the total wealth. The best results in per capita wealth were shown by East Asia and Pacific, as well as South Asia, where average annual growth rate of 5.8\% was achieved. In other regions, there was also an increase in per capita wealth, excluding Sub-Saharan Africa, where wealth per capita declined by $0.2 \%$ on average per year. An analysis of the countries within the Sub-Saharan region reveals that per capita losses of wealth affected a smaller number of large countries (such as Nigeria and Tanzania), while others achieved an increase.

Changes in the regional wealth composition point to the conclusion that the share of human capital has been reduced in the region of East Asia and Pacific, which is linked to the aging of the active population, but has increased in Europe and Central Asia, the region of South Asia, and also sub-Saharan Africa thanks to investment in education and increasing labor force.

Measuring wealth in different countries, in total and by individual components, is motivated by the concern for sustainable development, that is to preserve and increase the opportunities available to people. Bearing this in mind, it should continue with periodic wealth estimates to see changes in its size and structure. In the meantime, flow measures, such as the already mentioned adjusted net savings, could be used to manage the portfolio of different types of capital.

The World Bank's analysis shows that the ANS rate varies considerably among the regions of the world in the period 1995-2014. East Asia and Pacific, as well as South Asia, recorded a positive ANS rate of around 20\% of GDP. In Latin America and Caribbean, the ANS is smaller, but its share in the GNI is still significant and around 10\%. Sub-Saharan Africa, as the poorest region of the world, records the negative ANS almost every year of the observed period, owing primarily to the exhaustion of natural resources, while the contribution of education expenditures is positive. A deeper analysis by country shows that those who are rich in natural resources tend to have a negative ANS because they focus on the exploitation of natural resources in order to increase current income, but at the expense of future development (i.e. in an unsustainable manner). The „curse” of resource-rich countries is not inevitable. A positive example is Botswana, which has been very successful in achieving long-term growth and poverty reduction. This was largely the result of investing rents in building human capital, as a key resource of modern age.

It is important to note that the negative rate of the ANS is not quite a sure sign that the economy is on the unsustainable development path. The reason is the limitations in the calculation of ANS relating to agricultural land and human capital. If it is found that the rate of ANS in a country is $-10 \%$, policy makers should assume that the missing elements in the ANS calculation have grown at least for the same percentage, before they exclude the assumption that the development process is unsustainable [6]. 


\section{CONCLUSION}

Wealth and adjusted net saving are important synthetic indicators of sustainable development that can contribute to the successful realization of the Sustainable Development Goals, and above all Goal 17, which relates to the strengthening the means of implementation and revitalization of the global partnership for sustainable development [7]. Within this goal, the calculation of wealth and ANS can affect the coherence of policies and institutions, by providing a common and sound analytical framework for assessing sustainable development, as well as to improve the achievement of targets related to data, monitoring and accountability. Efforts to define adequate wealth and saving measures are also on the line of creating indicators, complementary GDP, which measures progress in the direction of sustainable development. They also contribute to the strengthening of statistical capacities in developing countries, which is incorporated into Objective 17. In conclusion, the indicators of wealth and ANS attach great importance to human capital, that is, education and health, which are highlighted as specific UN targets for the coming period.

\section{REFERENCES}

[1] Jovanović Gavrilović, B. (2013) Privredni razvoj sa ljudskim likom (Economic Development with Human Face), Univerzitet u Beogradu - Ekonomski fakultet, Beograd, p. 65.

[2] Salim, E. (2007) Paradigm of Sustainable Development. Institutionalising Sustainable Development, OECD Sustainable Development Studies, OECD, Paris, p. 28.

[3] World Bank (1997) Expanding the Measure of Wealth. ESD Studies and Monographs Series. 17.

[4] World Bank (2006) Where is the Wealth of Nations? Measuring Capital for the 21st Century, IBRD/ The World Bank, Washington, DC, p. 40.

[5] Lange, G-M., Wodon, Q., Carey, K. (eds.) (2018) The Changing Wealth of Nations - Building a Sustainable Future, World Bank Group, Washington, DC.

[6] World Bank (2011) The Changing Wealth of Nations - Measuring Sustainable Development in the New Millennium, IBRD/ The World Bank, Washington, DC, 37-38.

[7] United Nations (2018) The Sustainable Development Goals Report 2018, United Nations, New York, p. 13. 